\title{
Characteristics of the social protection system in rural society modernization: a policy approach
}

\author{
Z. Markaev ${ }^{1, *}, M$. Aytboev ${ }^{1}$, and $D$. Khaydarova ${ }^{2}$ \\ ${ }^{1}$ Tashkent State Agrarian University, University str., 2, Tashkent province, Uzbekistan, 100140 \\ ${ }^{2}$ Kokand State Pedagogical Institute, Turon str., 23, Kokand, Ferghana province, Uzbekistan
}

\begin{abstract}
In this research, the importance and characteristics of social protection in modernization of society were studied. The analyzes were based on the views of Western and Eastern scholars on the social protection of the population. In particular, aspects related to social protection, poverty reduction, education reform, employment and real income growth were scientifically and theoretically research. The results showed that the social policy of the state was aimed at maintaining the ultimate result of the reforms carried out by the state, maintaining social stability, increasing the standard of living of the population. Noteworthy, any countries, which planned implementing new policies and reforms on improving social sphere, need take account citizens as main influencing factor to those policies and reforms.
\end{abstract}

\section{Introduction}

The world is modernizing rapidly, which is having both negative and positive effects to society and human life, and the governments of many countries are trying to deter negatives of the modernization towards maintaining the stable socio-economic status of their citizens. It is stated that the ways and strategies chosen and proposed for the social protection of society should help countries to find a place in the world community $[1,2,11]$.

Today, the main goal and content of social modernization is to prepare society for life in a new industrial and innovative economy, the country's rapid sustainable and economic development, improving interethnic relations, establishing social relations based on the principles of law and justice. A new type of social relations between people is created by only socially oriented state based on the main principles of social justice, social partnership and citizen consent $[2,3,12]$. Good performance in maintaining and regulating various relations in society mostly references to developed countries, nevertheless, in developing countries including in Uzbekistan, a number of measures are being taken to develop social protection and regulate social relations.

For instance, presidential decree, No. 4947, on "Strategy for the five priority areas of development of the Republic of Uzbekistan for 2017-2021" was adopted, and it can be said that it was the most appropriate step taken towards ensuring the well-being and security of

${ }^{*}$ Corresponding author: bekchanovsanjar123@gmail.com 
people during the society modernization $[1,13]$. The fourth priority of the strategy is targeted at improving social sphere; consistent increase and development in employment and real incomes of the population aimed at the development of the social sphere, improve the system of social protection and health care, increase the socio-political activity of women, build affordable housing, development and modernization of road transport, engineering and communications and social infrastructure, education, culture, science; development of science, literature, arts and sports, and improvement of state youth policy [1].

Many studies carried out on the development of the social sphere in Uzbekistan, but effects of the adopted law and reforms on the development of the social sphere has not been studied well, therefore, this research focused on analysis of the existing policies and reforms towards identifying most influencing aspects of social protection system.

\section{Materials and methods}

In this research, the Republic of Uzbekistan was chosen as a study site (Fig. 1). The state is one of Central Asian countries, its area is $447,000 \mathrm{~km}^{2}$, and the country stretches $1,425 \mathrm{~km}$ from the west to the east and $930 \mathrm{~km}$ from the north to the south. Uzbekistan is the most populous country in Central Asia, with a current population of 34 million.

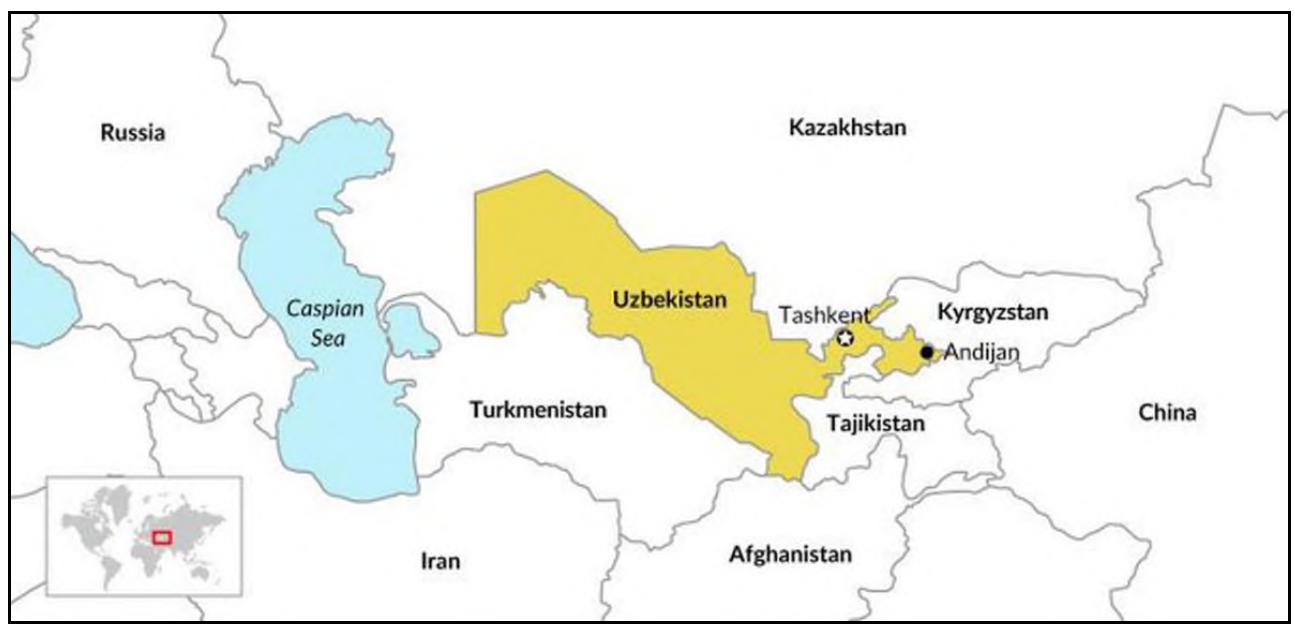

Fig. 1. Map of the study area.

Policy assessment method was employed in this research for analyzing existing policies and reforms on modernization of social sphere. In this case, two type of sources, national and international; treaties, policies, regulations and reforms on modernization of societies, main characteristics and importance of social protection system, were used.

\section{Results and discussion}

The first president of the Republic of Uzbekistan, Islam Karimov, developed the Five Principles of the transition period, which became known as the "Uzbek model" in the world, and the fourth principle defined as a strong social policy that took into account the complex demographic composition of the population and targeted improving social sphere during the transition period. Even the essence of the reforms carried out in our country was called "transition to a socially oriented market economy" from the side of international 
experts. It is considered that the transition from one socio-political system to another, especially the socio-political system, which completely contradicts the existing one, is always complicated. This is reflected sharply in the life of a certain part of the population. When moving from one system to the second, in particular, the old system of production, the existing economic integration naturally breaks down, consequently, everything needs to be reconstructed. Also, the form of ownership changes, the owners of state enterprises, even crop lands, change, the labor force was redistributed directly on the basis of the laws of the market economy. This means that it is also natural that the amount of people in need of social protection increases and declines. $95-98 \%$ of the knowledge about the existence accumulated until today is devoted to the problems of society, while the information that expresses human nature is even less than one percent of the sciences $[3,4]$.

The strong social policy was the principle directly determined by the president of the Republic and considered one of the important aspects of the Five Principles of transition to the market economy, that was, the principle aimed at supporting the least provided strata of the population, low-income families, disabled and orphan children, as well as the elderly alone. According to scientific evidence, the root of the country experience was linked to religious, philosophical, historical foundations. The history of the country showed that the role of state in the field of social policy and social sphere was very important and the strong spiritual-ideological approach was applied, which encouraged the support of the poor and others who were in need. In this regard, Amir Temur, Alisher Navoi, and Khoja Ahror Vali, who implemented the reforms towards improving social life. In that period, the main issues of the state, society and democratic development were the peace of citizens, protection of the necessary resources, and raising their spirituality. According to Abu Nasr Farabi, the people of "good people city" can support each other, support each other, ease their pain, unite for a single goal and through this they can achieve what they intend to do [3].

However, the inhabitants of an ignorant city do not aspire to happiness; they do not even know what happiness is, because people in ignorance did not find happiness. The famous poet, Alisher Navoi, said that in the development of society, it was very important to study and solve the problems of the existing lower stratum in society. Otherwise, the proposed measure and implementing policies and reform on improvement of society and social sphere would not be effective as planned. Clearly, absence of appropriate policy aimed at securing and improves life of lower stratum in society leads to social problems, such as inequality and increased crime.

At the end of the 19th and early 20th centuries, the first stage of the formation of the social protection system of the population was carried out. At this stage, a number of laws on social protection were developed in European countries. Social insurance was considered proper option to improve the social protection of the population [6]. In the 30ies of the 20th century, there was an economic crisis in European countries. As a result, the number of unemployed among the population increased, incomes of the population decreased, living conditions deteriorated. "Schools of population scientists" were created that studied the living conditions of the population in European countries and the USA towards solving those raised problems. In the 30-40 years of the 20the century in the USA, the manifestations of the "school of population scientists" E. Meyo, F. Retlisberg, M. Follet carried out a research among the population on social protection of the population. In their opinion, technology in the industry was directed by people, so bringing new technologies into the industry would make the labor force easy. After the Second World War, a single system of Social Security was formed in a number of countries [7].

Now, not only the active part of the population, but also the entire population were provided with social security and free medical care. In developed countries, the role of the state in the system of social protection of its population increased. The state pursued a 
strong social policy on the management and control of relations between the producer and the workers, improving the system of social protection of the population.

The outputs of the research showed that the system of social protection of the population in different states was concerned with the level of socio-economic development of the country. Noteworthy, any countries, which planned implementing new policies and reforms on improving social sphere, need take account citizens as main influencing factor to those policies and reforms [8]. It is considered that the effective system of social protection of the population in the country is a sign of socio-economic development of modern societies. It was observed that a rapid increase in the standard of living of the population in a country whose economy was prosperous.

Professor K. Abdurahmonov pointed out that social protection of the population was guarantee from the country that provided the population with opportunities and facilities for normal life. In other words, the system of social protection should be organized not only from the narrow outlines of the effectiveness of the market system, but also from the goal of solving the issues of ensuring real socio-economic efficiency [9]. Clearly, social protection system can be developed based on present-day requirements that citizens have.

In fact, the law, society or natural heritage expresses its internal connotations and begins to express itself clearly in social development. It is necessary that each person correctly understands the law and becomes its social being. "The law must be the walls of our house," said by the ancient Chinese wisdom, Confucius. The combination of social protection with democratic processes and the real life of people is an indicator of the individual's understanding of his dignity in the social space and time, his deviation from moral norms, as well as spiritual and educational formation. For the successful implementation of social protection, socio-political democratization and modernization are pivotal. "Democracy" as a political-philosophical concept expresses colorful phenomena such as people's power, electoral system, human rights, free thinking, conscience land, parliamentarism, political consciousness and participation in the management of political culture, society and state affairs, a free way of living [10].

Furthermore, people who participate in the process of Social Protection, which takes place in society, should feel that they are an active participant in this process and, accordingly, they need to try. Famous Russian philosopher C.N. Bulgakov argued that for social protection it was necessary, first of all, that was, to arouse the ardent interest of people in life and ensure that their psyche was healthy $[8,9]$.

Social protection of the population, some scientists have tried to understand through the following systems: first, the system of Social Security; second, the system of employment; third, the system of creating social benefits for some citizens, etc. This approach reflects the role of the state in solving existing problems. The state manages the level of social protection of the population through legislative and legislative acts, determines the minimum level necessity for making a living and, referring to it, determines the minimum amount of remuneration paid to labor, social payments, insurance contributions and types of social assistance, benefits, coordinates the activities of services in the field of social protection [6,9].

However, the most effective role in the management of the level of social protection of the population of the state is an expression from providing assistance in the organization of additional workplaces, including workplaces for the disabled, vocational training, retraining and raising the level of qualification. Also, in turn, social protection includes the following: Social assistance is the free transfer of cash, voucher or nature (including school meals) to the needy or households; Public Work Programs; denial of payment (for basic medical and educational services); and subsidies (i.e.: food, fuel).

Social insurance is a "payment program that includes compensation assistance in unforeseen circumstances related to illness, trauma, disability, spouse or parent's death, 
motherhood/paternity, unemployment, old age and pet/agricultural crops." Social assistance services are for those who face social risks such as violence, exploitation, discrimination and social loneliness. "Programs in the labor market- " active (facilitating participation in the labor market) or passive (ensuring minimum standards of employment)."

A number of laws were developed and adopted on social protection of the disabled, on Youth Policy and on increasing the role of women in society and the life of the state, and on other issues, a number of decrees and resolutions were adopted to support the low-income stratum of the population, workers of budgetary organizations (servicemen, workers working in education, health, sports. In particular, on August 4, 2020, the President of the Republic of Uzbekistan adopted the resolution № PP-4797 "on additional measures to automate the procedures for providing state social services and assistance to the population". Accordingly, a new transparent and fair information system, "single register of social protection, was launched in Uzbekistan, which was very handy when working with the needy population. Such reforms, on the one hand, allowed the state to maintain and enrich the spiritual and educational potential that reached people, on the other hand, to support market reforms [11].

So, the main goal of the reforms is to improve the life of the people, to ensure free living of citizens, to develop, to actively engage in creative work, to spend a productive life, to achieve the enrichment of the content of life. The fact that the fourth priority direction of the strategy of action was devoted to the issues of development of the social sphere. A number of necessary measures, such as the provision of employment to the population, the quality of social protection of the low-income family and population, the need for social protection, the conduct of extensive reforms in health care, the role and participation of women and girls in public political life, the protection of motherhood and childhood, rapid and urgent ambulance care were considered. The President addressed to the Parliament of the country on January 24, 2020 that the majority of the population in the regions, especially in the villages, did not have sufficient high income. As in any country, Uzbekistan has low-income population strata, which were about 12-15 percent. [3]. Furthermore, the president stated that poverty reduction would awakening the entrepreneurial spirit in the population, the realization of economic and social policy.

During today's pandemic, as well as various natural and technical disasters in the country, comprehensive supports in term of financial were given to many people, who were in need that was the highest level of humanity. Furthermore, the agenda and sustainable development goals (SDGs) until 2030 years was basis for the fight against poverty in all countries. In such conditions, social protection systems play an important role, because they are aimed at protecting the population from social, economic and natural hazards. In addition, effective social protection systems contribute to the active participation of all groups of the population in economic growth processes, contribute to the reduction of inequality and thereby support sustainable and inclusive social development [11].

For this reason, many countries include the creation and implementation of comprehensive social protection systems to their national strategies and development plans, thereby ensuring the security of revenue and the support of all people in the life cycle. Despite this progress, 73 percent of the world's population only has partial access to complex social protection systems or does not have it at all. Many developed and developing countries want to connect their efforts more closely with the principles of the agenda for the period up to 2030 years, and its main goal is to ensure prosperity for all based on a common partnership and human dignity. 


\section{Conclusions}

Summarizing all, firstly, the social policy of the state was aimed at maintaining the ultimate result of the reforms carried out by the state, maintaining social stability, increasing the standard of living of the population. Secondly, ensuring the continuity of the social protection system played important role towards help people, who were in need, during global crisis like pandemic situation. Thirdly, the system of social protection of the population in the different states was associated with the level of socio-economic development of the country. The market economy should be socially oriented and, above all, aimed at the interests of society. Fourthly, the needs of enterprises and organizations in the tertiary, secondary special education system, the showed that development of the practice of personnel training was very important both in terms of employment of graduates and in terms of the development of industries, production, service and service sectors.

Therefore, it is necessary to further improve the granting of preferential microcredits to graduates of vocational colleges themselves to ensure that they have a place of work independently, to start individual labor and entrepreneurial activities. Fifth, social stability was important for the population of multinational Uzbekistan, and the main goal of the reforms was to improve the life of the people, to ensure the free existence of citizens, to develop, actively engage in creative work, to spend a productive life, to achieve the enrichment of the content of life.

\section{References}

1. Presidential Decree No. 4947 of the Republic of Uzbekistan, February 7 (2017) (in Uzbek)

2. A. A. Primova, International scientific review, 1, 245-249 (2020)

3. G. Mukhamadiyeva, G. Mukaldyeva, Z. Karasheva, A. Khamzin, Y. Buribayev, Z. Khamzina, Journal of Advanced Research in Law and Economics, 8(30), 2498-2503 (2017)

4. C. Valadas, Social Policy \& Administration, 51(2), 328-347 (2017)

5. D. Ernazarov, Arkhiv Nauchnykh Issledovaniy, 4(2), $42-44$ (2019) (in Russian)

6. V. Inglxart, K. Veltsel, Sociology, 1, 447-451 (2011)

7. M. V. Ilin, A. Melvil, YU. Fedorov, Policy, 4, 142-164 (1996)

8. N. Vodolazskaya, Virtual Economics, 2(1), 82-94 (2019)

9. S. D. Khodjaev, Sociology and law, 3, 39-47 (2020)

10. Presidential Decree No.4797 of the Republic of Uzbekistan, June 21 (2020) (in Uzbek)

11. S. Isaev, S. Khasanov, Y. Ashirov, A. Gofirov, T. Karabaeva, In E3S Web of Conferences, 244, 02047 (2021)

12. U. Mukhtorov, In E3S Web of Conferences, 244, 03013 (2021)

13. S. K. Isaev, R. U. Rakhmonov, S. S. Tadjiev, G. I. Gozeiv, S. Z. Khasanov, In IOP Conference Series: Earth and Environmental Science, 614(1), 012147 (2020) 